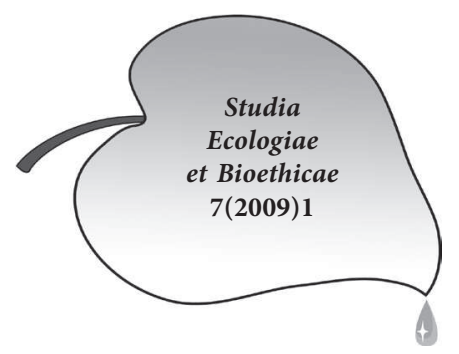

\title{
Zmiany kondycji fizycznej polskiej młodzieży w ciągu ostatnich dekad
}

Kondycję fizyczną, o której mówi tytuł niniejszego wystąpienia, uznaję za pozytywne kryterium zdrowia. Na co dzień jesteśmy raczej przyzwyczajeni do charakteryzowania stanu zdrowia przez symptomy negatywne, epidemiologiczne, jak statystyki zachorowalności, hospitalizacji, śmiertelność, czy przez wyniki diagnoz klinicznych wykrywających określone jednostki chorobowe. Dzieje się tak dlatego, że nauki medyczne i praktyka lekarska, nie tylko zresztą w naszym kraju, są nastawione na wykrywanie i zwalczanie chorób, a nie na ocenę zdrowia. I nie zmienił tego stanu fakt, że już od pół wieku Światowa Organizacja Zdrowia lansuje definicję, że zdrowie to nie jest brak choroby lecz dobrostan organizmu i osiągnięcie pozytywnego samopoczucia człowieka (Karski, 1997).

Ocena zdrowia przez pryzmat braku choroby, a więc uwzględniająca kryteria negatywne, ujawnia się podczas przekrojowych badań młodzieży, kiedy lekarz, jeśli nie wykryje żadnej choroby, kwalifikuje badanego do kategorii „b.z.”, co znaczy „zdrów”. Osób zakwalifikowanych do takiej kategorii może być $80 \%$ czy $70 \%$, to zależy od ostrości przyjętych kryteriów kwalifikacyjnych. Reprezentanci medycyny tą częścią badanych zaliczonych grupy „b.z.” dalej się nie interesują, choć oczywiście w tej grupie występują znaczne indywidualne różnice w stanie zdrowia pozytywnego. Wynika to $\mathrm{z}$ tego, że medycyna na progu XXI wieku ciągle ma charakter naprawczy, a nie profilaktyczny. Niemal nie zajmuje się zdrowiem pozytywnym. Tym są zainteresowane inne dziedziny, jak wychowanie fizyczne, wychowanie zdrowotne, antropologia fizyczna czy auksologia.

Do oceny zdrowia wg symptomów pozytywnych stosuje się kryteria auksologiczne a nie epidemiologiczne. W przypadku dzieci i młodzieży wykorzystuje się najczęściej przejawy rozwoju fizycznego (procesy rośnięcia, tempo dojrzewania), wydolność fizyczną, sprawność ruchową, samopoczucie i samoocenę siebie.

Pozytywne kryteria zdrowia przyjęliśmy w ogólnopolskich badaniach młodzieży szkolnej, jakie powtarzamy co dziesięć lat w wylosowanych szkołach $\mathrm{z}$ terenu całego kraju. Badaniami obejmujemy materiał, który jest reprezentatywny dla całej generalnej populacji w wieku 7-19 lat, jak również reprezentatywny 
dla poszczególnych województw, dla regionów Polski o odmiennych warunkach ekologicznych, dla odrębnych środowisk społecznych i dla miejscowości zamieszkania o różnej skali urbanizacji. W niniejszym doniesieniu przedstawiam informacje o wynikach badań z roku 1979, kiedy zdjęciem auksologicznym objęliśmy ponad 233 tysięcy osób (Trześniowski 1990), z roku 1989, kiedy przebadaliśmy ponad 219 tysięcy uczniów (Przewęda i Trześniowski 1996) oraz z roku 1999, kiedy zebraliśmy materiał liczący ponad 73 tysiące wylosowanych dzieci i młodzieży (Przewęda i Dobosz 2003).

Wyniki powtarzanych co dekadę pomiarów, prób i obserwacji reprezentatywnej próbki uczniów, których przykład jest pokazany, dają obraz poziomu kondycji fizycznej młodzieży, inaczej mówiąc obraz jej zdrowia pozytywnego, oraz wykazują wieloletnie tendencje zmienności, tzw. trendy sekularne, pozwalające przewidywać dalsze przemiany w tym zakresie, co może być pomocne w podejmowaniu ogólnokrajowych lub regionalnych decyzji społecznych, zdrowotnych, edukacyjnych i kulturowych, czyli w prowadzeniu racjonalnej polityki zapobiegającej potencjalnym dewiacjom i asymetriom rozwojowym młodzieży.

Uzyskane przez nas rezultaty nie zaskakują oryginalnością czy odkrywczością. Raczej potwierdzają zjawiska i tendencje znane $\mathrm{z}$ innych badań, także $\mathrm{z}$ opinii medialnych, a nawet $\mathrm{z}$ ulicznego oglądu polskiej rzeczywistości - np. że współczesna polska młodzież jest coraz wyższa, że jednak coraz częściej trafiają się między nimi osobnicy z nadwagą, nawet otyli, co może zapowiadać groźbę epidemii otyłości zbliżającą się do nas ze Stanów Zjednoczonych, a w Europie z Wielkiej Brytanii. Z pewnością przedstawiany przeze mnie materiał pochodzący z ostatniego dwudziestolecia XX wieku ma tę dodatkową wartość, że pokazuje, jak zmieniała się kondycja fizyczna polskiej młodzieży w latach, kiedy w naszym kraju dokonywały się burzliwe i zasadnicze transformacje ekonomiczne i społeczne, czyli powstawały nowe warunki wzrastania i dojrzewania badanych chłopców i dziewcząt.

Pierwsza konkluzja, jaka się nasuwa przy analizie wyników pomiarów i prób w kolejnych dekadach, to konstatacja, że rozwój fizyczny polskich dzieci i młodzieży szkolnej oceniany na podstawie wskaźników somatycznego wzrastania i osobniczego dojrzewania jest prawidłowy. Ciągle wyraźne trendy sekularne wysokorosłości i przejawy przyspieszania dojrzewania płciowego, przypadające na coraz młodsze kategorie wieku kalendarzowego, dowodzą istnienia sporych rezerw rozwojowych i mówią o ich uruchamianiu w ontogenezie współczesnych młodych osobników. To świadczy o zdrowiu pozytywnym młodych polskich generacji, jak się czasem to określa, o ich „biologicznej wartości”. Ilustracja tej tezy jest widoczna na rycinie 1 , przedstawiającej zmiany średniej wysokości ciała chłopców w roku 1979, 1989 i 1999. 


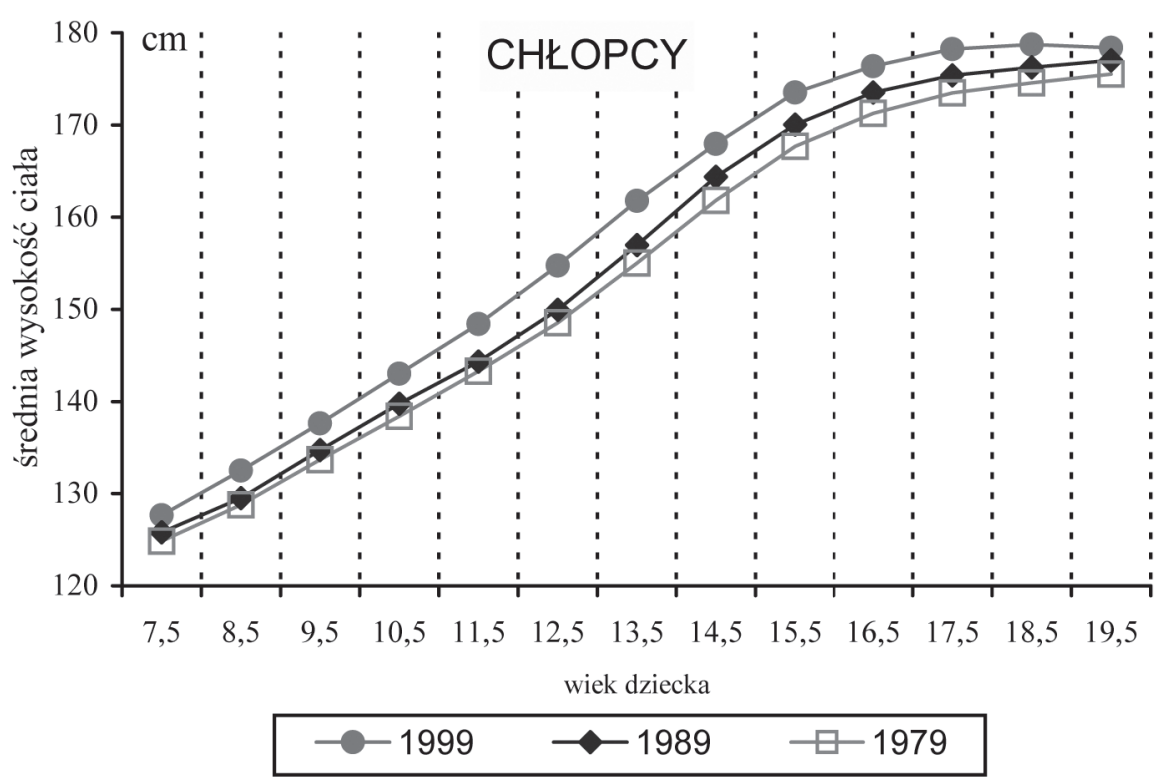

Ryc. 1. Średnie wysokości ciała chłopców w roku 1979, 1989 i 1999

Wykresy średnich arytmetycznych wysokości ciała pokazują, że w każdej kolejnej serii badań chłopcy (u dziewcząt wystąpiło analogiczne zjawisko) byli wyżsi, przy czym w roku 1999 chłopcy najstarsi, u których proces rośnięcia już został zakończony, przewyższali swoich rówieśników z roku 1989 o około 2,5 $\mathrm{cm}$, a rówieśników z roku 1979 o około 4,5cm, co jest dużą różnicą, oczywiście istotną statystycznie. Różnice dekadowe w grupach wieku, w których przypada skok pokwitaniowy wzrastania, były dwukrotnie wyższe, co jest dowodem akceleracji dojrzewania. Warto tu dokładniej podać, że najwyższe tempo wzrastania chłopców w roku 1979 wystąpiło w grupie 14-latków, w roku 1989 w grupie 13,5-latków, a w roku 1999 w grupie 13-latków, co także dowodzi ciągle występujących u polskiej młodzieży przejawów akceleracji dojrzewania. Wg auksologów wcześniejsze dojrzewanie jest zjawiskiem pożądanym, jako pozytywne kryterium zdrowia, dowodzi bowiem potencjalnych zdolności rozwojowych ujawniających się wraz z poprawą warunków życia dziecka. Rycina 2 obrazuje analogiczne zjawisko akceleracji dojrzewania polskich dziewcząt w dekadzie 1989-1999 na podstawie wieku menarche. 


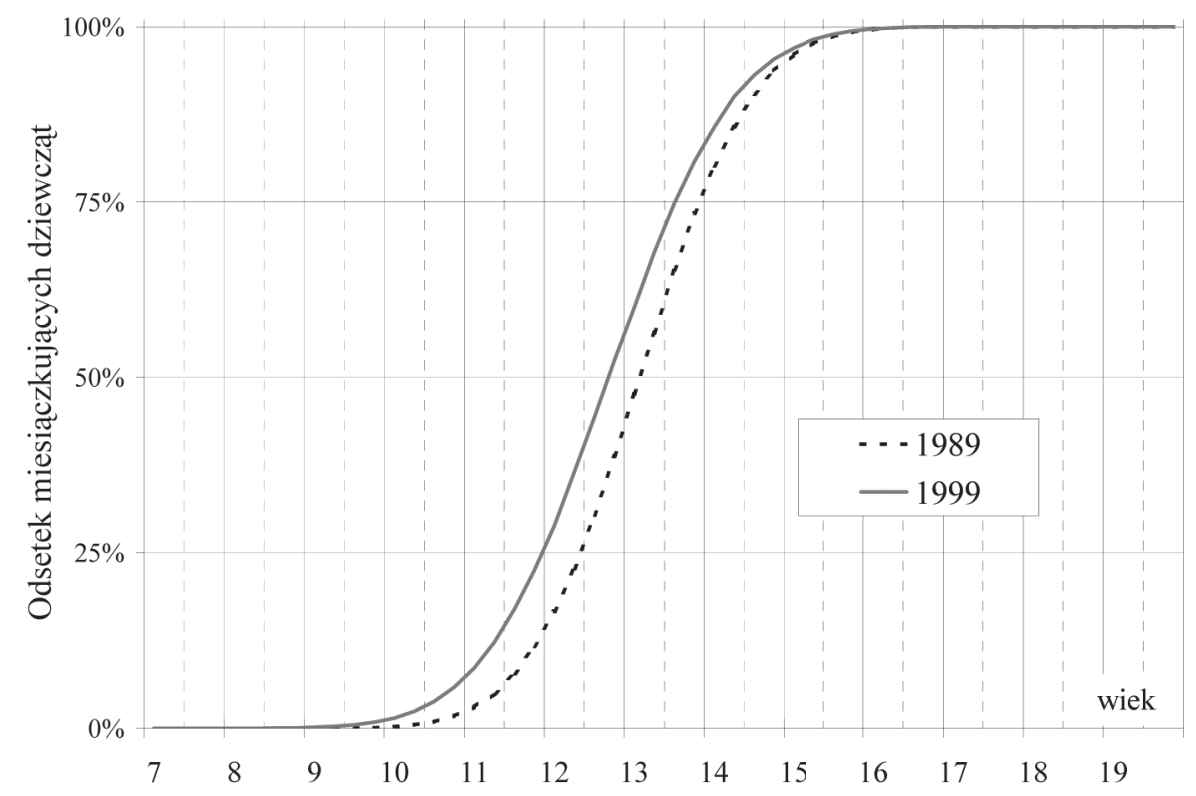

Ryc. 2. Obniżenie się średniego wieku menarche dziewcząt w latach 1989 - 1999

W latach 1979-1999 średnia masa ciała chłopców przyrastała proporcjonalnie do średniej wysokości, na co wskazuje wskaźnik smukłości (Ryc. 3). Wskaźnik smukłości, jeden ze wskaźników wzrostowo-wagowych, jest tym wyższy, im szczuplejsza jest budowa ciała, ponieważ oblicza się go dzieląc wysokość ciała przez pierwiastek trzeciego stopnia z masy ciała. Jak widać na rycinie 3, po zakończeniu ontogenetycznych procesów rośnięcia chłopcy najstarsi z kolejnych serii naszych badań byli podobni pod względem relacji wysokości do masy ciała, natomiast dekadowe różnice wskaźnika smukłości, przypadające na wcześniejsze fazy wzrastania, obrazują ujawniającą się co dziesięć lat akcelerację, między innymi wcześniejszy skok pokwitaniowy we wzrastaniu.

Ten sam wskaźnik smukłości u płci żeńskiej (Ryc. 4.) ujawnił wyraźne zjawisko smuklenia sylwetki dziewcząt po okresie pokwitania. Interpretacja tego fenomenu jest prosta: na masę ciała można wpływać działaniem intencjonalnym, np. dietą czy aktywnością ruchową, podczas kiedy możliwość bezpośredniego wpływania na wysokość ciała jest niemal żadna. Dekadowe zmiany w szczupłości sylwetek, różne u chłopców i dziewcząt, są wyrazem podyktowanych modą świadomych regulowań masy ciała. Moda u dziewcząt ciągle zaleca szczupłą sylwetkę, a u chłopców - sylwetkę umięśnioną, co skłania ich do przyjmowania specjalnych odżywek, do uprawiania ćwiczeń kulturystycznych w siłowniach itp. 


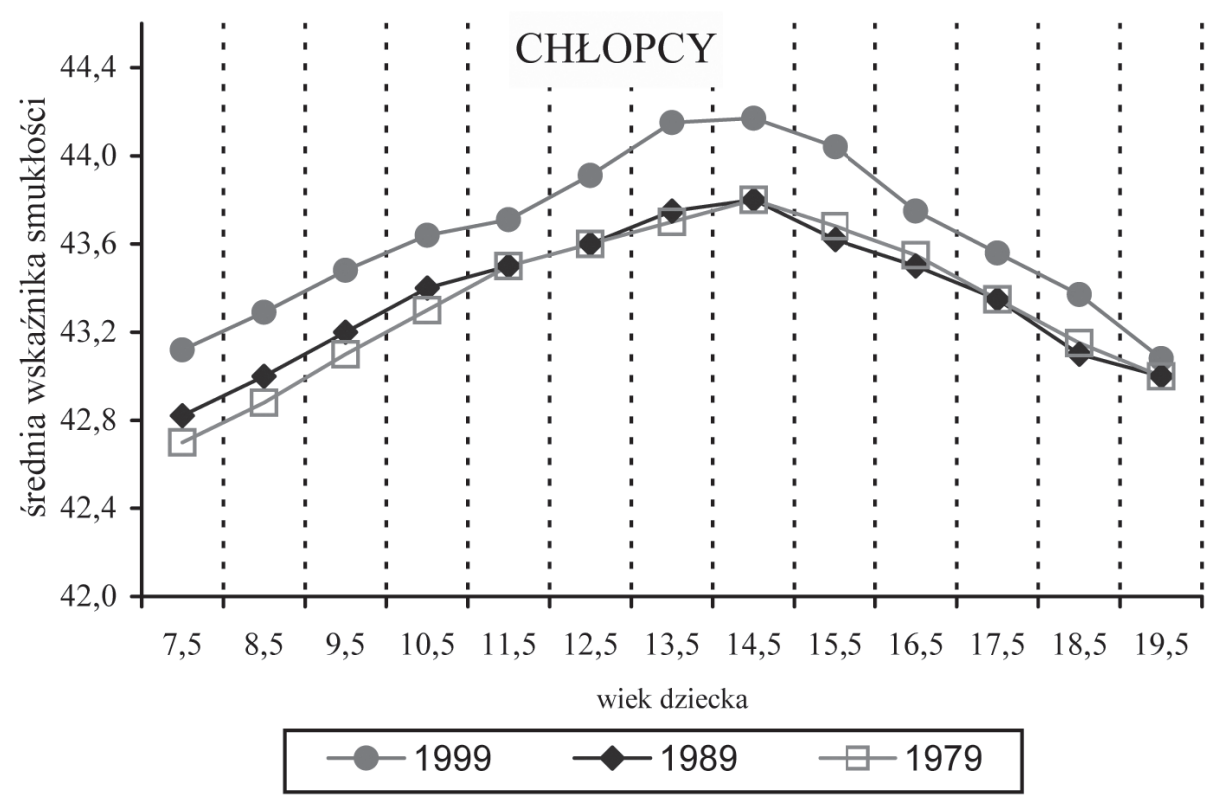

Ryc. 3. Średni wskaźnik smukłości chłopców

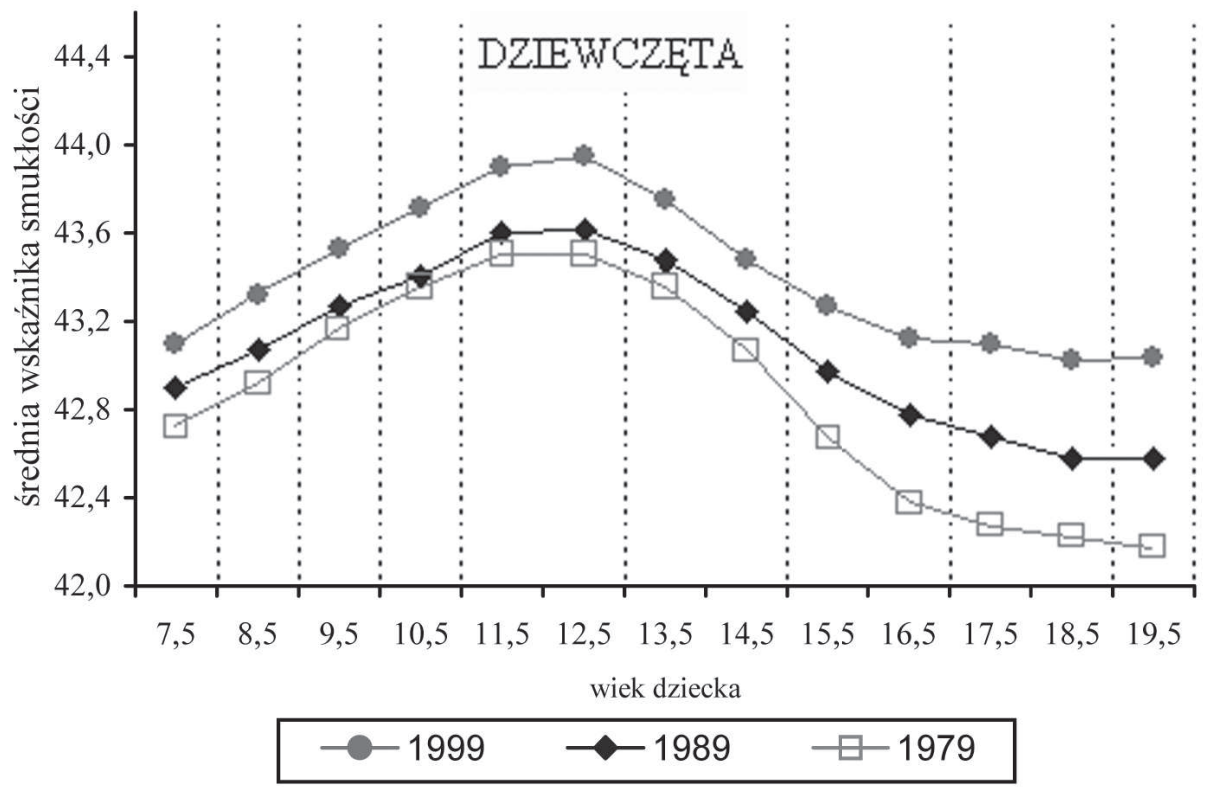

Ryc. 4. Średni wskaźnik smukłości dziewcząt 
Optymistyczny wniosek o zadowalajacym zdrowiu pozytywnym młodzieży, jaki otrzymaliśmy z pomiarów somatycznych i z akceleracji dojrzewania, nie znalazł potwierdzenia w obrazie wydolności fizycznej i sprawności ruchowej badanych uczniów. A sprawność fizyczna i wydolność robocza organizmu są trafniejszymi wskaźnikami kondycji, czyli więcej mówią o zdrowiu pozytywnym dzieci i młodzieży, niż same przejawy rośnięcia i dojrzewania. Niepokojącym sygnałem jest fakt, że trend sekularny wysokorosłości oraz akceleracja rozwoju osobniczego nie pociągnęły za sobą wzrostu wyników w próbach motorycznych, czego się spodziewaliśmy. Bo przecież większy chłopiec powinien dalej skoczyć i szybciej pobiec, a bardziej masywny powinien uzyskać lepszy rezultat w ściskaniu siłomierza. A tu, jak wynika z naszych badań, z każdą dekadą mamy młodzież coraz większą somatycznie i coraz słabszą motorycznie. Zwykliśmy nawet pokoleniowe zmiany w kondycji fizycznej młodzieży porównywać do modelu rozwierających się nożyc, ponieważ coraz lepszemu rozwojowi morfologicznemu towarzyszy coraz gorszy poziom sprawności i wydolności fizycznej. Ta asymetria rozwojowa między somatyką i motoryką pogłębia się z każdym dziesięcioleciem, burząc w ten sposób strukturę kondycji fizycznej i stanowiąc zagrożenie dla zdrowia pozytywnego młodych Polaków w następnych dekadach. Regres sprawności i wydolności fizycznej pokazuję na kilku przykładach (Rycina 5-7), wybranych z licznych prób ruchowych, tworzących międzynarodową baterię testów oraz europejską baterię testów EUROFIT, jakie w badaniach stosowaliśmy. Wyniki wszystkich prób sprawności i wydolności fizycznej są dostępne w książce na temat kondycji fizycznej polskiej młodzieży (Przewęda i Dobosz 2003).

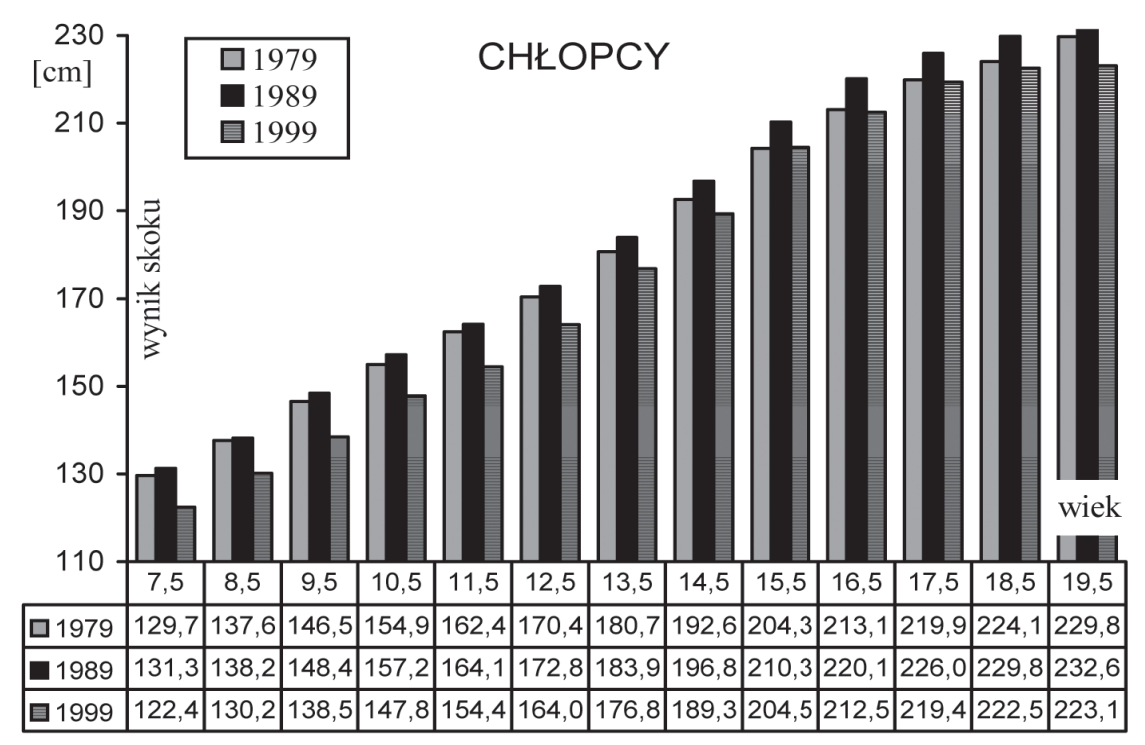

Ryc. 5. Średnie wyniki skoku $w$ dal z miejsca chłopców 


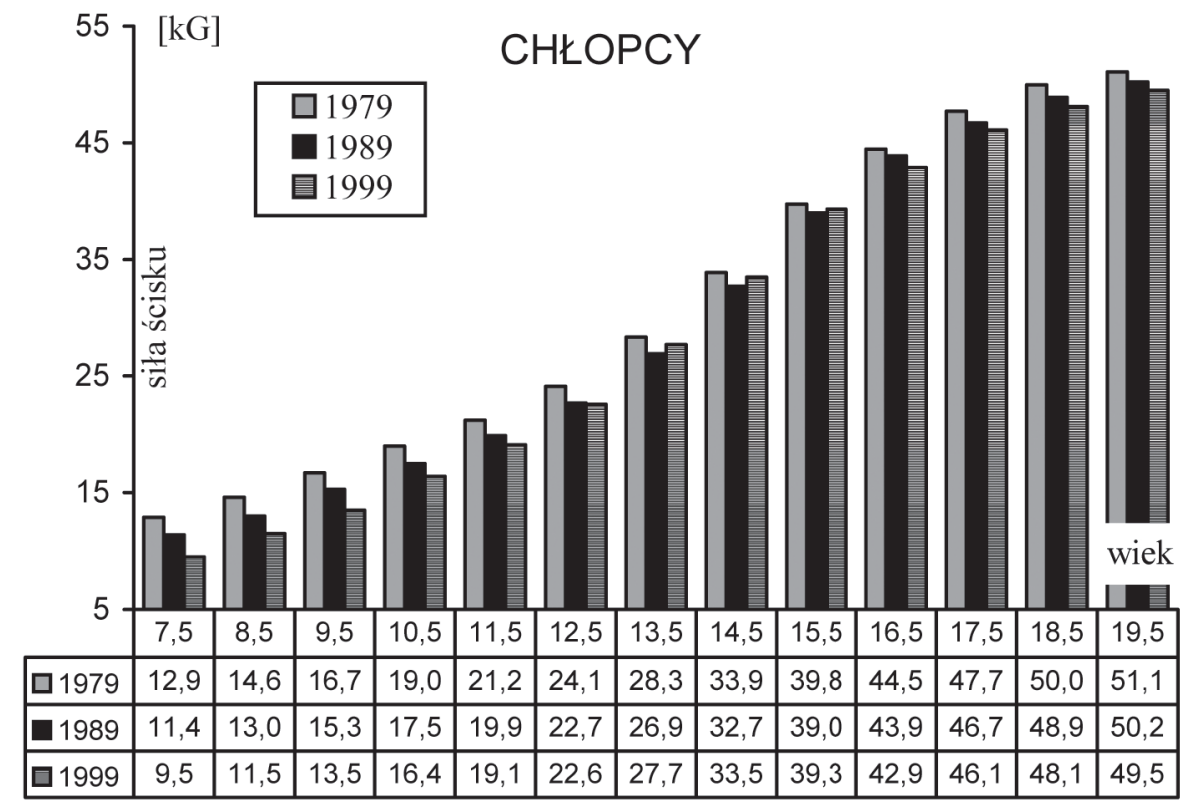

Ryc. 6. Średnie wyniki dynamometrycznego pomiaru siły ręki chłopców

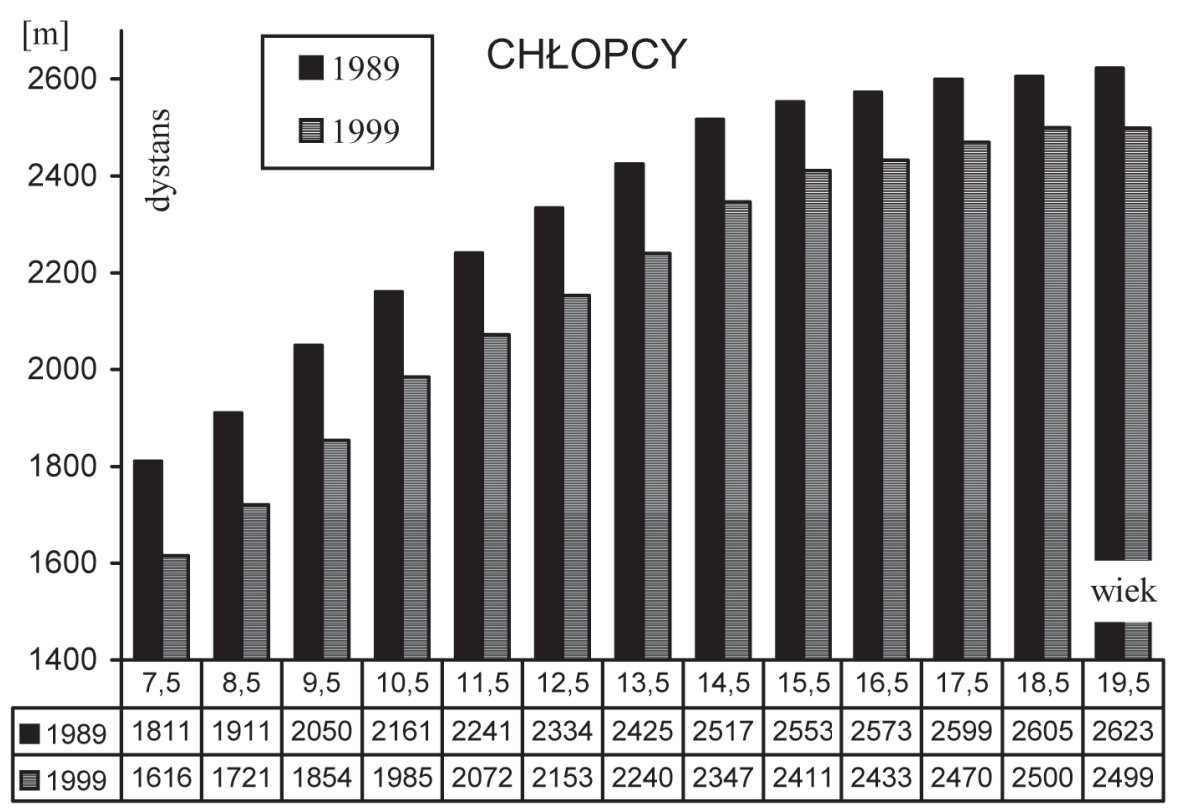

Ryc. 7. Spadek wydolności fizycznej chłopców mierzonej testem Coopera w latach 1989-1999 
Na szczęście pogłębiającą się rozbieżność w kierunkach przemian sekularnych w rozwoju somatycznym i motorycznym naszej młodzieży można powstrzymać, inaczej mówiąc można zahamować dalsze rozwieranie się nożyc prowadzące do asymetrii $w$ ontogenezie, a w efekcie do obniżania się poziomu zdrowia pozytywnego młodych polskich generacji. Bowiem motoryczność osobnicza - w odróżnieniu od indywidualnych procesów rośnięcia - jest wyćwiczalna, podatna na trening kondycyjny i na nauczanie czynności ruchowych. Oznacza to, że przez zwiększenie aktywności ruchowej polskiego społeczeństwa i zmianę jego trybu życia na bardziej sportowo-rekreacyjny można będzie powstrzymać narastające zagrożenia zdrowotne młodzieży.

Ten trudny program społeczno-zdrowotny jest najczęściej rozumiany jako zadanie polskiej szkoły, ponieważ szkoła obejmuje swymi wpływami niemal całą młodzież w ciągu kilkunastu lat kształtujących ludzkie postawy i ponieważ w szkole pracują wykształceni w tym kierunku fachowcy, nauczyciele wychowania fizycznego i wychowania zdrowotnego, którzy potrafią zapobiegać degradacji ruchowej uczniów i wychowywać ich do zdrowego stylu życia. Sama „nasza szkoła" nie jest w stanie spełnić tak trudnych oczekiwań społecznych i musi mieć wsparcie w każdym domu rodzinnym i w licznych stowarzyszeniach oraz organizacjach rządowych i pozarządowych. Niestety na początku XXI wieku przeciętny polski dom rodzinny nie stanowi środowiska efektywnego w budzeniu u dzieci potrzeb ruchowych i w uczeniu ich jak te potrzeby należy zaspokajać.

Aktualny obraz kondycji fizycznej młodzieży nie jest taki sam w całym kraju i nieco różni się w poszczególnych regionach, w odmiennych środowiskach i warstwach społecznych. Przykładowo, panuje przekonanie, że dzieci wzrastające w korzystnych warunkach dojrzewają wcześniej. Różnice średniego wieku menarche, jaki odnotowano u dziewcząt w poszczególnych województwach w roku 1999, przedstawia rycina 8. Najniższy wiek dojrzewania przypadł u dziewcząt województwa mazowieckiego (łącznie z aglomeracją warszawską), zaś najpóźniej przejawy pokwitania ujawniły się w województwach podkarpackim i łódzkim. 


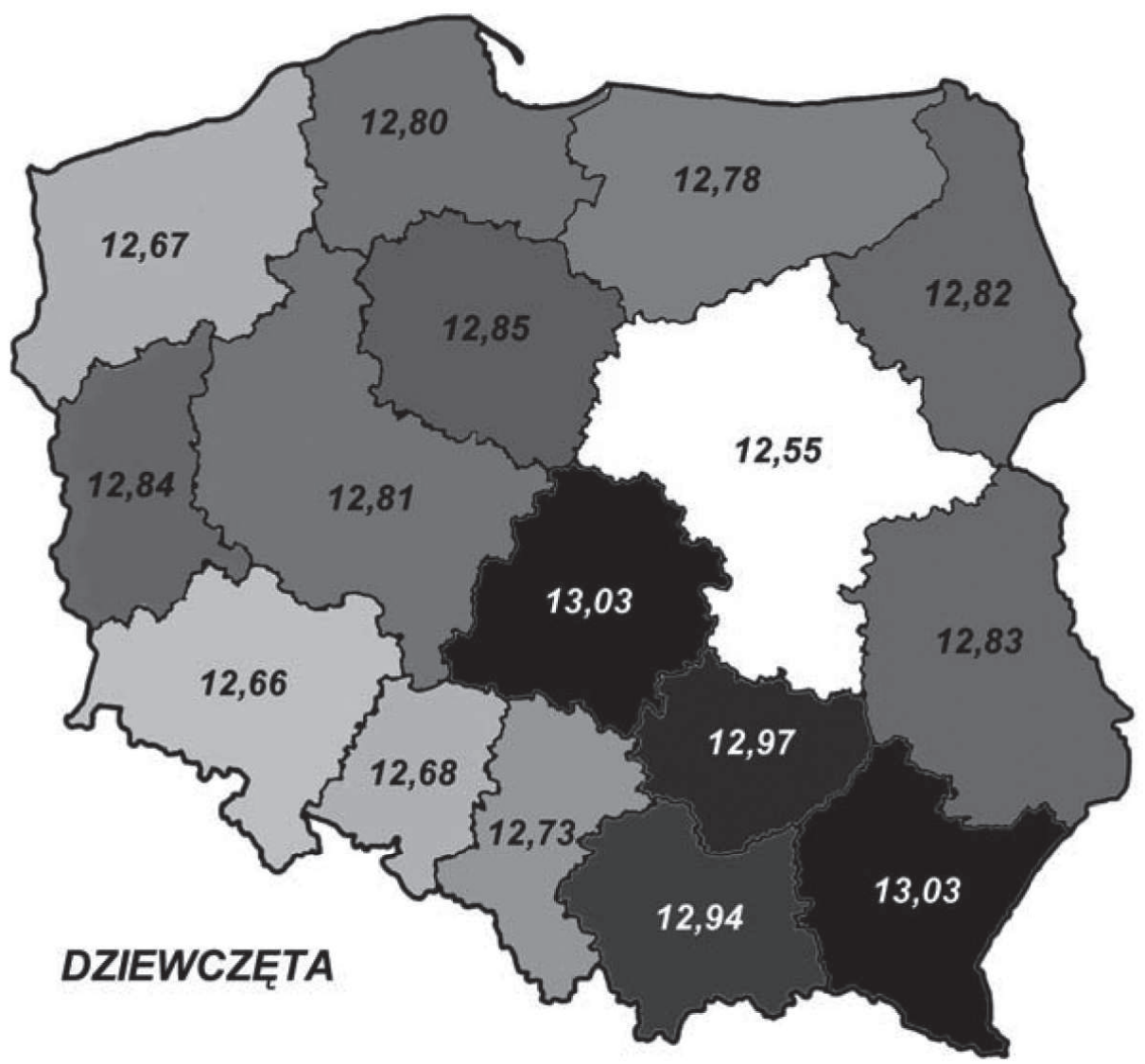

Ryc. 8. Przeciętny wiek menarche dziewcząt w poszczególnych województwach w 1999 r.

W poszukiwaniu ekologicznych czynników środowiskowych wpływających korzystnie i niekorzystnie na rozwój fizyczny i motoryczny dzieci wybrane zostały dwa obszary: pierwszy najczystszy ekologicznie, który utworzyły województwa mazursko-warmińskie i podlaskie (tzw. „zielone płuca Polski”) oraz drugi najbardziej skażony, mianowicie województwa górnośląskie i dolnośląskie, uznane za „obszary ekologicznego zagrożenia”. Rycina 9 pokazuje wyższy poziom wydolności fizycznej dzieci wzrastających w warunkach ekologicznie korzystnych. Ponadto młodzież zróżnicowano również ponadto pod względem ich społecznoekonomicznych warunków życia, obliczając tzw. SES, czyli status ekonomicznospołeczny (Trzcińska, 2002). 
Ryszard Przewęda
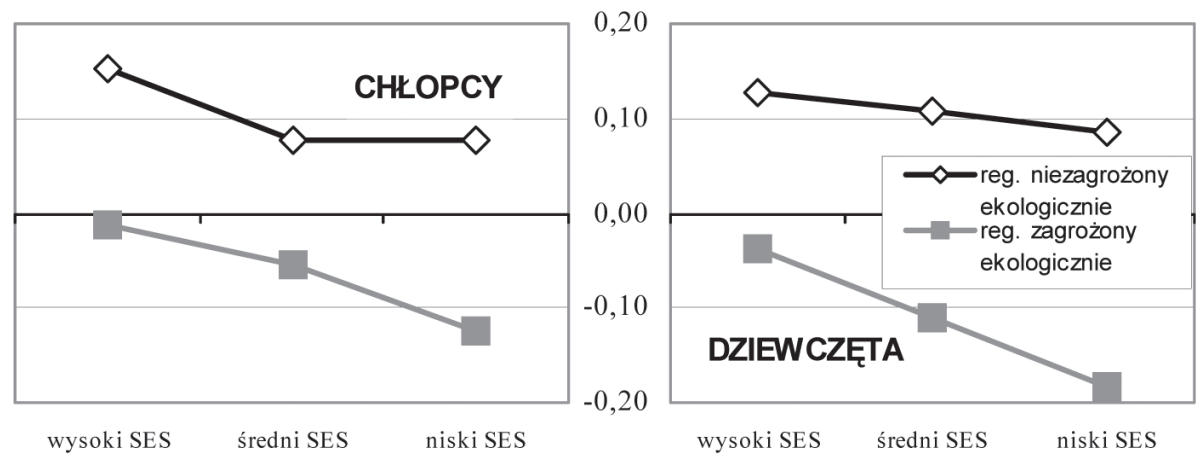

Ryc. 9. Różnica poziomu wydolności fizycznej mierzonej testem Coopera w regionach czystych ekologicznie i skażonych

W polskiej literaturze auksologicznej wiele pozycji poświęcono zróżnicowaniu rozwoju fizycznego, motorycznego i umysłowego dzieci z miast i wsi [por. np. Siniarska 1984; Hulanicka i wsp. 1990; Łaska-Mierzejewska i Olszewska 2003; Nowacka-Dobosz 2003; Zagórski i Skład (red) 2003; Saczuk (red) 2006; Wolański 2006 i inni]. Na rycinach 10 - 14 pokazane są przykłady takich różnic zanotowanych w naszych ogólnopolskich badaniach w roku 1999.

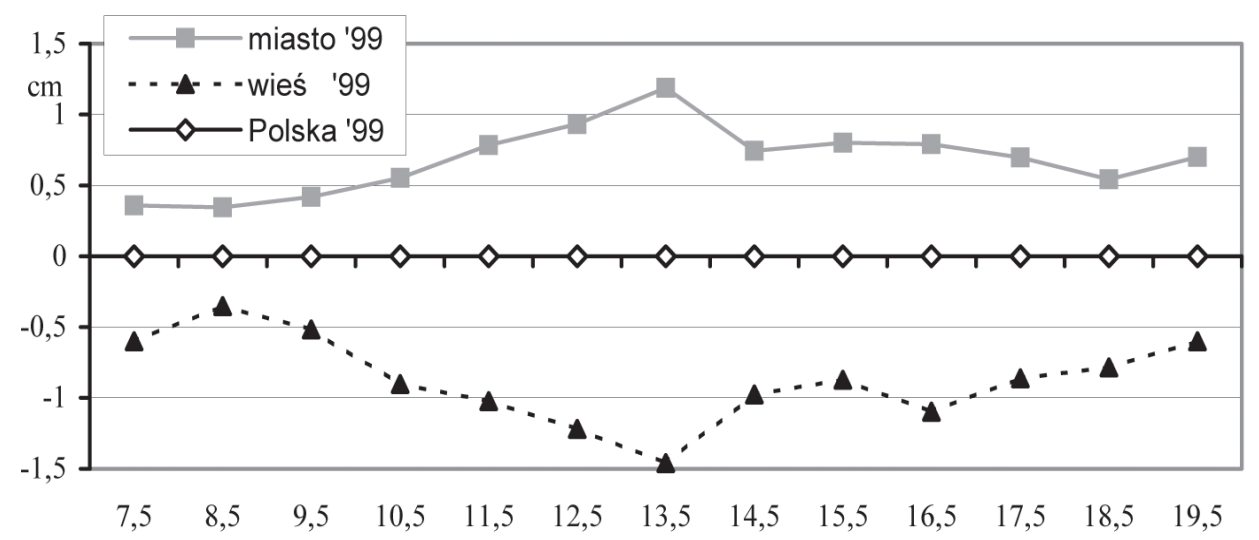

Ryc. 10. Różnice w średniej wysokości ciała chłopców pochodzacych z miast i wsi, unormowanej na średnią populacji ogólnopolskiej z roku 1999 


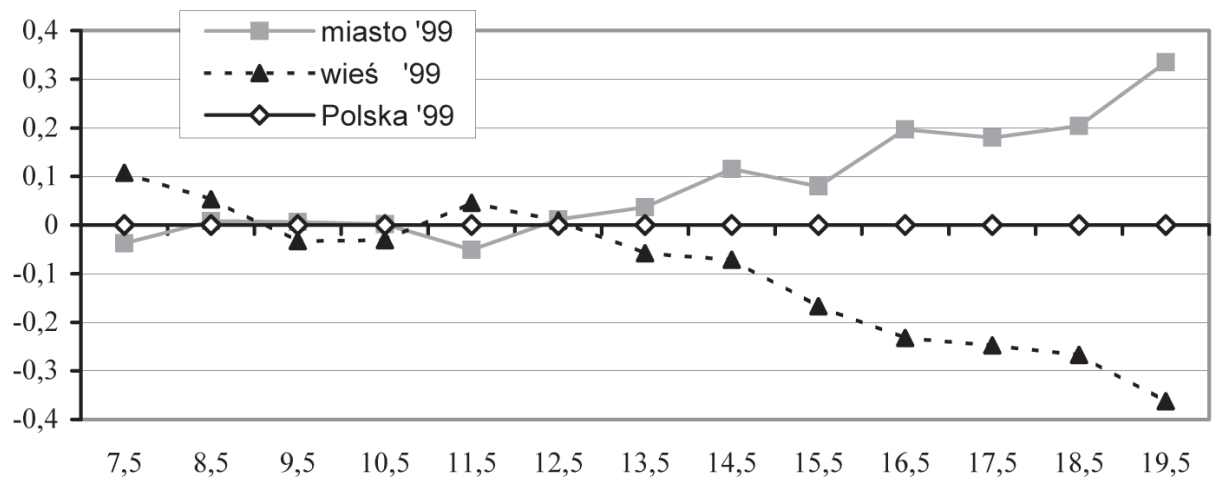

Ryc. 11. Różnice we wskaźniku smukłości dziewcząt pochodzących z polskich miast i wsi (wartości unormowane na średniq populacji ogólnopolskiej)
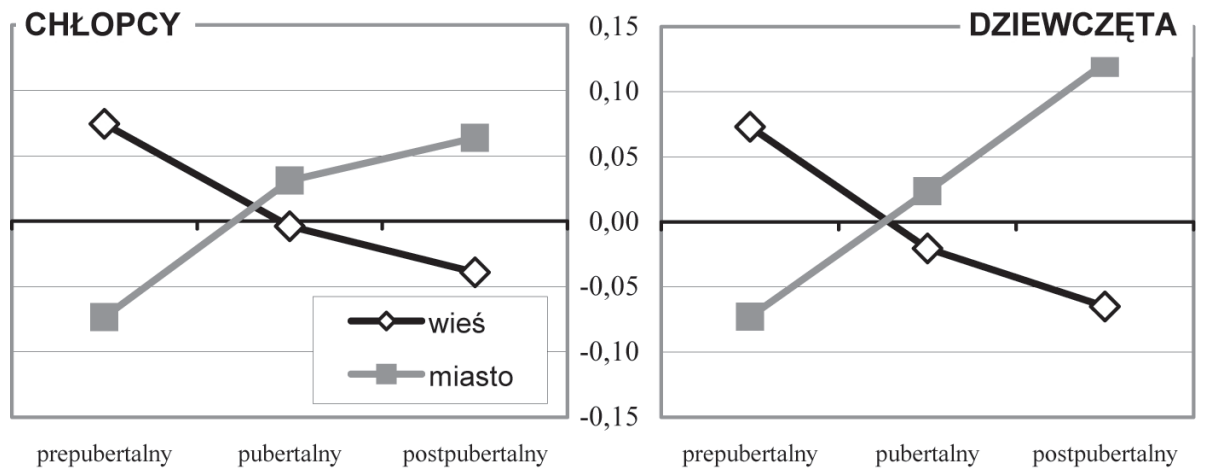

Ryc. 12. Porównanie unormowanych wyników biegu 4 x 10 m młodzieży wiejskiej i miejskiej $w$ trzech fazach dojrzewania
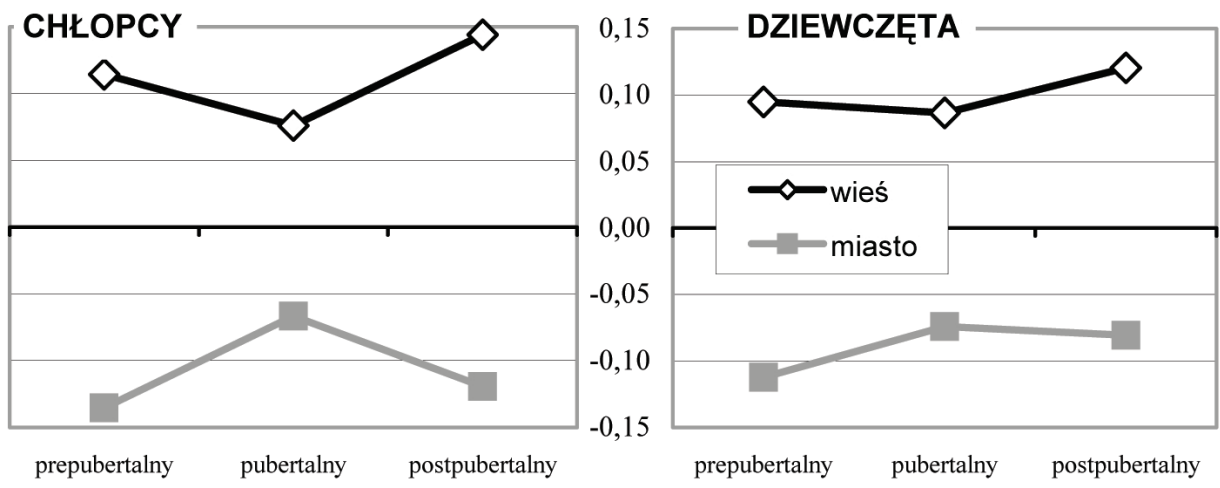

Ryc. 13. Porównanie unormowanych wyników testu siły ścisku ręki młodzieży wiejskiej i miejskiej w trzech fazach dojrzewania 

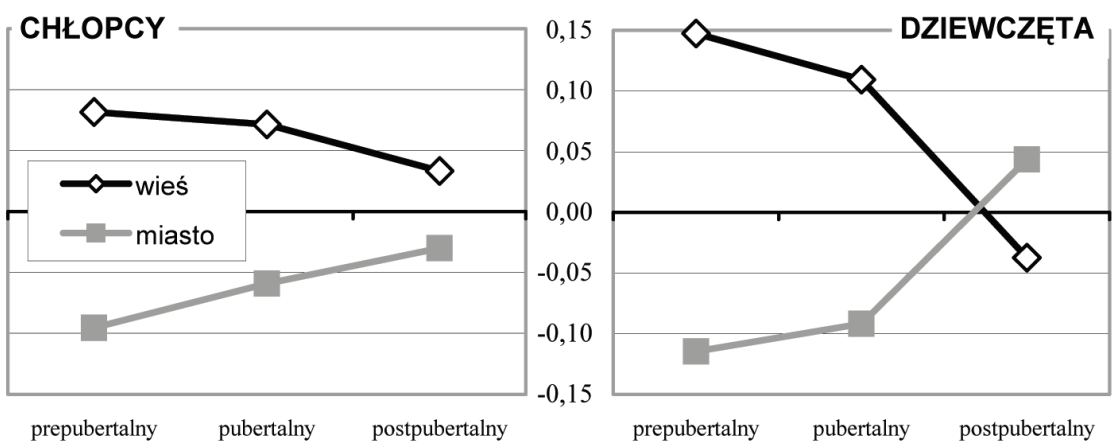

Ryc. 14. Porównanie wydolności fizycznej na podstawie unormowanych wyników testu Cooper'a młodzieży wiejskiej i miejskiej w trzech fazach dojrzewania

Na zakończenie przedstawiony zostanie wpływ rodzinnych warunki życia na kondycję fizyczną dzieci [Bielicki 1992; Siniarska 1994; Wolański 2006; Wolański i A Siniarska (red.) 1982; i in.]. Uwarunkowania rodzinne bywają zresztą odmienne w poszczególnych regionach kraju, co jest związane z poziomem urbanizacji miejsca zamieszkania itp., inaczej mówiąc warunki rodzinne wchodzą w interakcje ze środowiskowymi uwarunkowaniami społeczno-kulturowymi oraz biogeograficznymi, tworząc swoisty konglomerat czynników środowiskowych. Przykładem niech będą dwie zmienne charakteryzujące sytuację rodzinną dzieci badanych w roku 1999. Te zmienne to status wykształcenia obojga rodziców i liczba dzieci w rodzinie. Obie zmienne okazały się przydatne $\mathrm{w}$ analizie materiałów $\mathrm{z}$ badań $\mathrm{w}$ latach 1979, 1989 i 1999, można natomiast powątpiewać, czy w badaniach następnych będą one równie trafnie charakteryzować status rodzinny badanych dzieci wobec szybkiego upowszechniania się wyższego wykształcenia w polskim społeczeństwie oraz wobec bogacenia się niektórych warstw społecznych, gdzie większa liczba dzieci nie obciąża ekonomicznie rodziny i nie wpływa niekorzystnie na poziom życia jej członków.

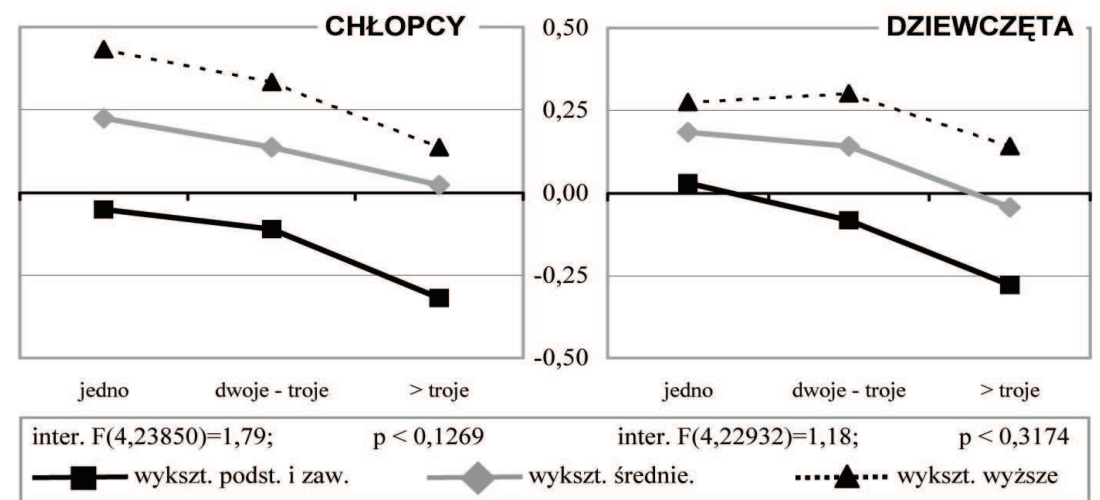

Ryc. 15. Unormowane wartości wysokości ciała młodzieży w grupach wykształcenia obojga rodziców i liczby dzieci w rodzinie (analiza wariancji) 


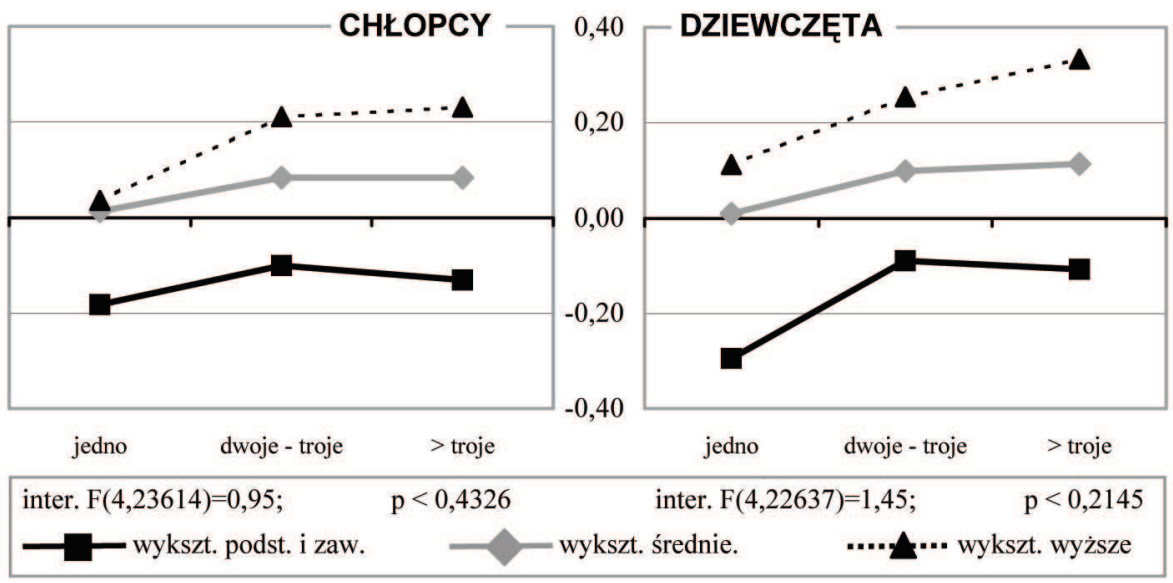

Ryc. 16. Unormowane wyniki skoku $w$ dal młodzieży $w$ rodzinach różniących się dzietnością i statusem wykształcenia rodziców (analiza wariancji)

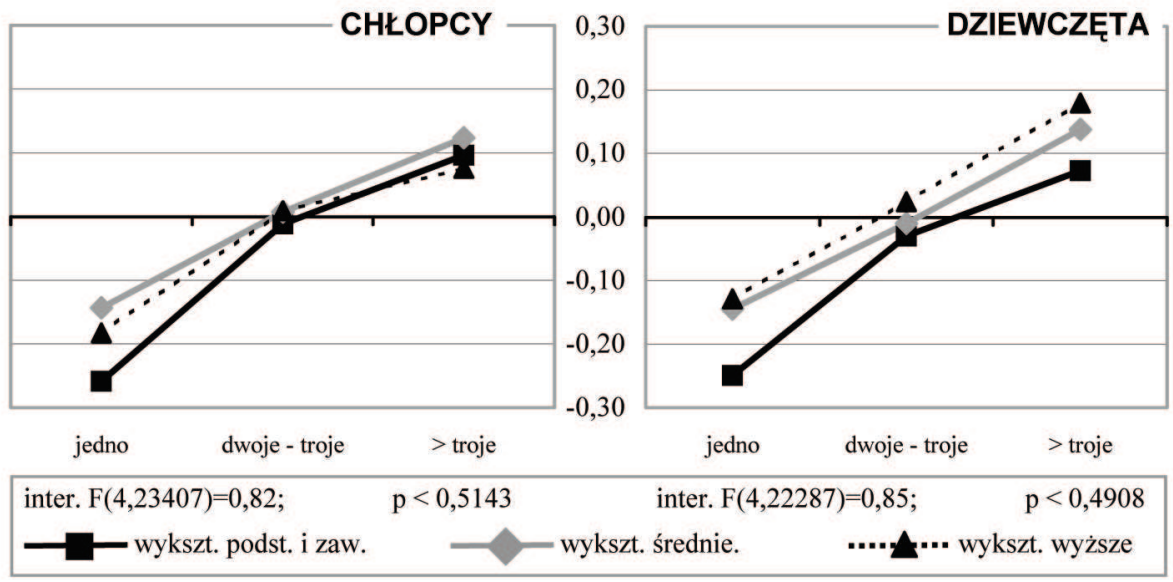

Ryc. 17. Unormowane wyniki w 12 minutowym teście Coopera młodzieży pochodzacej $z$ rodzin różniących się liczba dzieci i wykształceniem rodziców (analiza wariancji)

Wyniki licznych polskich badań auksologicznych dowodzą, że wyższy poziom wykształcenia rodziców wpływa korzystnie na rozwój fizyczny oraz - choć może mniej jednoznacznie - na rozwój ruchowy dzieci. Niniejsze badania potwierdzają te zależności, co ilustrują ryciny 15 i 16. Natomiast czynnik dzietności rodziny jest ujemnie skorelowany z procesami wzrastania i dojrzewania, ale dodatnio koreluje z poziomem sprawności i wydolności fizycznej. Oznacza to, że zwykle najgorszy rozwój motoryczny prezentują jedynacy, którzy charakteryzują 
się najlepszymi osiągnięciami we wzrastaniu i dojrzewaniu, za to im jest więcej dzieci w rodzinie, tym lepiej rozwijają się one pod względem ruchowym. Należy przypuszczać, że w rodzinach wielodzietnych pozytywnym czynnikiem dla rozwoju sprawności i wydolności fizycznej stają się wspólne zabawy ruchowe oraz, że większy wpływ na zachowanie i aktywność dzieci wywierają rodzinne wzorce osobowe, których jest tym więcej im więcej członków rodzina liczy.

\section{Piśmiennictwo}

Bielicki T., Nierówności społeczne w Polsce w oczach antropologa. Nauka Polska 1992, 3:3-18. Cooper K. H., The Aerobics Way. New York 1981, Banton Books.

Hulanicka B., Brajczewski Cz., Jedlińska W., SŁawińska T., Waliszko A., Duże miasto, małe miasto, wieś - różnice w rozwoju fizycznym dzieci w Polsce. Monografie Zakładu Antropologii PAN, 11, Wrocław 1990.

KARSKI J. B., Pozytywne mierniki zdrowia z perspektywy promocji zdrowia. W: Współczesne Potrzeby i Możliwości Pomiaru Zdrowia, Materiały krajowej konferencji naukowej, J. B. Karski, H. Kirschner i J. Leowski (red.), Warszawa 1997, Wyd. Ignis.

Łaska-Mierzejewska T., Olszewska E., Antropologiczna ocena zmian rozwarstwienia społecznego populacji wiejskiej w Polsce w okresie 1967-2001. Badania Dziewcząt. Studia i Monografie, 95, AWF, Warszawa 2003.

NowACKA-Dobosz S., Rozwój i sprawność fizyczna dzieci i młodzieży z różnych poziomów urbanizacyjnych. Rozprawa doktorska AWF, Warszawa 2003.

Przewęda R., Dobosz J., 2003: Kondycja fizyczna polskiej młodzieży. Studia i Monografie AWF, 98, Warszawa.

PrzewęDA R., Trześniowski R., 1996: Sprawność fizyczna polskiej młodzieży w świetle badań z roku 1989. Studia i Monografie AWF, Warszawa.

SiniARSKA A., Rozwój psychomotoryczny mieszkańców niektórych terenów Polski o różnym stopniu uprzemysłowienia. Zeszyt Naukowy, 31:121-132, AWF Kraków 1984.

Siniarska A., Rozwój biologiczny dzieci i młodzieży z kilku wybranych regionów Polski na tle warunków życia rodziny i pewnych cech biologicznych rodziców. Studies in Human Ecology, Suplement 1/1994: 89-194.

SACZUK J. red., Uwarunkowania rozwoju dzieci i młodzieży wiejskiej. Tom I i Tom II. AWF ZWWF w Białej Podlaskiej. Biała Podlaska 2006.

TRzciŃska D., Rozwój i sprawność fizyczna dzieci i młodzieży z regionów o różnym stopniu skażenia środowiska. Rozprawa doktorska AWF, Warszawa 2002.

TRześniowski R., Rozwój fizyczny i sprawność fizyczna młodzieży szkolnej w Polsce. Z Warsztatów Badawczych AWF, Warszawa 1990.

WolańsKi N., Specyfika rozwoju mieszkańców wsi jako wyraz przystosowania do środowiska. W: Uwarunkowania Rozwoju Dzieci i Młodzieży Wiejskiej”, J. Saczuk (red), 1/ 2006: 9-38.

Wolański N., Rozwój Biologiczny Człowieka. Wydawnictwo Naukowe PWN, Warszawa 2006.

Wolański N., Parizkova J., Sprawność Fizyczna a Rozwój Człowieka. SiT, Warszawa 1976.

Wolański N., Siniarska A. (red.), Ekologia Populacji Ludzkich, Ossolineum, Wrocław 1982.

ZAGóRSKi J., SkŁad M. (red.), Uwarunkowania rozwoju dzieci i młodzieży wiejskiej. Materiały z konferencji, Instytut Medycyny Wsi. Lublin 2003. 


\title{
Changes in physical fitness of Polish youth during the last three decades
}

\begin{abstract}
SUMMARY
Physical development, rate of sexual maturation, physical fitness, working capacity and general wellbeing of the organism are the main criteria of the health status of children and youth. The cross-sectional studies were organized in ten-year-intervals in the randomly selected Polish schools representing the whole nation. The studies took place in 1979, 1989 and 1999 and included children and youth aged 7-19 years. The results demonstrate the continuous positive secular trend showing more intensive physical growth and earlier maturation. These observations give the evidence of a rather good health status of the present young generation. However, changes in the level of physical fitness and working capacity of youth present the decreasing tendency during this 20-year-period. The changes in motor performance are better indicator of the general health status than the rate and level of physical development. The results of this paper show the picture of so called "opening scissors", which means that even though the children and youth in 1999 were better physically developed (taller and heavier) than children studied in 1999 and 1989, their motor abilities were showing the gradual decrease during this period of time. The possible causes of this event have been presented and discuss in this paper.
\end{abstract}

